\title{
The Impact of Foreign Technology and Embodied R\&D on Productivity in Internationally Oriented and High-Technology Industries in Egypt, 2006-2009
}

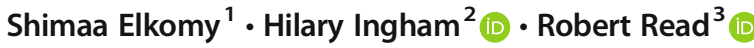

Received: 14 August 2019 / Revised: 7 July 2020

Accepted: 4 August 2020

Published online: 30 September 2020

(C) The Author(s) 2020

\begin{abstract}
This paper investigates the domestic productivity and spillover effects of foreign technology and embodied R\&D on Egyptian manufacturing industries, 2006 to 2009. It also analyses the heterogeneous sectoral effects of technology transfer by focusing specifically on the productivity effects on highly internationalized and technology-intensive industries. These are expected to have greater absorptive capacity with respect to foreign technology and therefore larger productivity effects because of their greater exposure to foreign competition and greater technological capacity respectively. This study is the first to analyse the efficiency effects of foreign technology by classifying industries in this manner. It finds that foreign technology and embodied R\&D have positive and significant industry-specific effects on domestic productivity and TFP in technology-intensive industries but that these are weaker in internationally oriented industries. The study suggests that only technologicalintensive industries in Egypt have sufficient absorptive capacity to assimilate foreign technology effectively. The paper's findings highlight the key role of foreign technology in domestic productivity growth, subject to the absorptive capacity of the domestic labour force, and the need for improved policies to promote the domestic benefits of technology transfer through the accumulation of local technological competences.
\end{abstract}

Keywords Foreign direct investment $\cdot$ Embodied R\&D Economic growth $\cdot$ Sectoral productivity - Spillover effects · Egypt

Electronic supplementary material The online version of this article (https://doi.org/10.1007/s10842-02000349-x) contains supplementary material, which is available to authorized users.

Robert Read

r.read@lancaster.ac.uk

Extended author information available on the last page of the article 


\section{Introduction}

The transfer of foreign technology is a critically important conduit for developing countries to acquire advanced techniques and innovations in order for them to improve productivity and increase economic growth. The effectiveness of such transfers through learning and their efficient utilization, however, is highly dependent upon the absorptive capacity of a host country's human capital stock and the magnitude of the technology gap with the source country. Industrialized economies have invested heavily in R\&D and human capital to develop innovative production methods and proprietary technology resulting in both technological progress and the accumulation of substantial stocks of knowledge. Many developing countries have acquired foreign technology embodied in inflows of foreign direct investment (FDI) and/ or imports of capital equipment but these transfers have generally been less successful in that they have not stimulated the anticipated improvements in productivity. The economic growth effects of technological progress in developing countries are argued to be subject to critical constraints that are not present in most industrialized economies. In particular, persistent and unresolved structural and institutional constraints and impediments to innovation and technical advancement, including a lack of appropriate policies, to foster the accumulation of relevant knowledge necessary for the successful adoption of new technologies.

This paper analyses the effects of the transfer of foreign technology and its embodied R\&D on domestic industrial productivity with respect to Egypt from 2006 to 2009. As is the case for many developing countries, foreign $\mathrm{R} \& \mathrm{D}$ is a vitally important source of technology; the share of domestic R\&D in Egyptian GDP is $0.7 \%$, of which only $8 \%$ is undertaken by the business sector (UNESCO 2019). The paper follows Reggiani and Shevtsova (2018) in testing the importance of existing technological capacity and the extent to which foreign technology and its embodied R\&D generate heterogeneous domestic productivity effects and technology spillovers between industries. This is accomplished by classifying industries according to their openness to trade and technological intensity. Those sectors that are more internationally oriented and have a greater degree of technological intensity can be expected to possess a greater capacity to adapt more advanced foreign technologies - i.e., greater absorptive capacity — and therefore generate larger beneficial learning and efficiency spillover effects. By grouping Egyptian manufacturing industries in this manner, this study is the first to capture the effect of industry-level stocks of international $R \& D$ using the unbiased weighting approach, as suggested by Lichtenberg and de la Potterie (1998).

The next section presents an overview of the relevant literature on channels through which advanced foreign technologies are transferred to developing countries and the determinants of their productivity effects. This is followed by a discussion of the estimation methods utilized in the paper and a description of the data. The empirical results and their implications are discussed in Section 5. Some conclusions and policy implications are presented in the final section.

\section{Theoretical Foundation and Review of the Literature}

Endogenous growth theory regards the international transfer of innovation and advanced technology as a critically important determinant of long-run economic growth, particularly for those countries lacking in indigenous R\&D-i.e., developing countries. Analogous to the 'catch-up' theory of growth (Gerschenkron 1962), the rate of technology diffusion will be 
more rapid the greater the extent of the technological gap with advanced economies. The primary determinant of variations in growth rates across countries is differences in total factor productivity (e.g., Easterly and Levine 2001; Caselli 2005) which are attributable, in great part, to national policies (Beck et al. 2000), including international trade and foreign direct investment (FDI). Trade and FDI are the principal channels for the diffusion of technological progress between countries, with foreign innovations and technologies being embodied in inflows of capital goods, intermediate products and final goods and services (see, for example, Coe and Helpman 1995; Keller 1998; Hejazi and Safarian 1999; de la Potterie and Lichtenberg 2001). These inflows may also generate positive technology spillovers through learning-bydoing and demonstration effects (Javorcik 2004). The magnitude of such spillovers however, depends upon the extent to which such tacit knowledge can be assimilated; i.e., domestic absorptive capacity.

Many developing countries have acquired foreign technology through trade and FDI, but the empirical evidence indicates that this has not necessarily led to the anticipated improvements in domestic productivity (e.g., Khan and Reinhart 1990; Lee 1995; Mazumdar 2001; Caselli and Wilson 2004; Ajakaiye and Page 2012; Nwaogu and Ryan 2015; Koo and Perkins 2016). The principal explanation for this shortfall in performance is the poor quality of policy design and implementation to promote the knowledge accumulation necessary for the adoption of more advanced technologies (Lall and Wangwe 1998; Lall and Pietrobelli 2002; Hanushek 2013; Koo and Perkins 2016). Nevertheless, the main driver of technological change in developing countries has been imports of capital goods and technology spillovers (Lall and Wangwe 1998). The notable success of many high growth economies in Southeast Asia in recent decades is the outcome of explicit policies to transform fundamentally their levels of technological sophistication and the magnitude and quality of their human capital stocks.

Technological progress and growth in developing countries are partly dependent upon their openness to both international trade and FDI, which are themselves correlated. Bhagwati (1978) argues that greater openness to trade attracts increased inflows of FDI, while the growth effects of FDI increase with trade openness. Several studies find support for this latter relationship for developing countries (Balasubramanyam et al. 1996; de Mello 1999; Read 2008) although Borensztein et al. (1998) also suggest that such growth is a non-linear function of domestic absorptive capacity; i.e., it is dependent upon a minimum threshold stock of human capital. Further, Lichtenberg and de la Potterie (1998) demonstrate that the growth effects of foreign $R \& D$ are greater the more open to trade is the host economy.

The effects of technology transfer and spillovers on domestic productivity are analysed in an extensive empirical literature. The accumulation of imported capital contributes significantly to technological progress in developing countries (Brada and Hoffman 1985), including the generation of significant technology spillovers (Coe et al. 1995). Imported technologies and new varieties of intermediate goods are also associated with higher manufacturing productivity resulting from increased specialization in production (Grossman and Helpman 1991). Most cross-country studies investigating the effects of FDI on recipient countries, both industrialized and developing, find significant support for positive domestic productivity effects of foreign technology, directly as a result of technology transfers but also as a result of spillovers (e.g., Coe and Helpman 1995; Lee 1995; Lichtenberg and de la Potterie 1998; Hejazi and Safarian 1999; Keller 2000, 2004; Mazumdar 2001; Caselli and Wilson 2004; Cecchini and Lai-Tong 2008). Individual country-level findings are broadly similar although the effects tend to be heterogeneous, with larger productivity growth in those sectors with greater technological intensity. Evidence for India shows that foreign technology in chemicals, pharmaceuticals, 
electronics and machinery generate significant positive productivity effects (Hasan 2002). Lower technology sectors however derive larger productivity effects from additional domestic capital. Further, more productive firms experience significantly positive efficiency effects arising from foreign technologies (Bas and Berthou 2017). In China, only those industries close to the technological frontier are found to generate significant productivity spillovers from foreign technology (Chuang and Hsu 2004). Evidence from Hungary offers support for Grossman and Helpman (1991) and the availability of additional varieties of intermediate inputs (Halpern et al. 2006).

The host country growth effects of technology transfer depend upon the extent of the technology 'gap' with the source country and, by implication, the absorptive capacity of domestic human capital to assimilate more advanced technology (Glass and Saggi 1998). The 'relative backwardness' hypothesis, according to which technologically laggard countries exhibit faster growth via diffusion (Findlay 1978; Wang and Blomström 1992) however, receives only limited empirical support. In an analysis of manufacturing productivity in 27 industries across seven Asian economies, Chamarbagwala et al. (2000) find that the growth effects of foreign technology are greater for more technologically sophisticated countries; i.e., those with more abundant human capital and skilled labour. Malikane and Chitambara (2017) test the effects of the technology gap and growth for 45 African economies but find no evidence to support more rapid catch-up. In Chile in the late 1970s and early 1980s, only import-competing manufacturing sectors exhibited positive productivity gains from innovation and technical progress channelled by foreign trade and gave rise to a reallocation of domestic resources (Pavcnik 2002). Similarly, Bloom et al. (2016) find significant productivity gains through increased innovation and advanced technologies for European firms as a result of increased Chinese import competition.

Building on the work of De Long and Summers (1993), Temple and Voth (1998) and Hendricks (2000) suggest that the productivity effects of adopting superior technology in the presence of human capital are considerable. The critical issue is whether the absorptive capacity of the human capital stock is sufficient for the optimal adoption of foreign technologies. Further, inflows of foreign technology may significantly enhance the domestic skill base, particularly in more trade-oriented and import-competing sectors. Burstein et al. (2013) demonstrate that advanced foreign technology tends (unsurprisingly) to be skill-biased, with knock-on effects on labour demand and possible 'crowding out', as in the cases of Ireland (Barry and Bradley 1997), Fiji and Samoa (Driffield and Read 2004). Productivity gains arise from the shift of domestic factors into more skill-intensive sectors as per Pavcnik above - along with a significant increase in the skill premium (Burstein and Vogel 2017).

Technology spillovers via backward or upstream vertical linkages between foreign firms and local suppliers are regarded as an important additional means of generating beneficial domestic productivity effects (Javorcik 2004). The magnitude of such spillovers again depends upon the technology gap, domestic absorptive capacity and the willingness of foreign affiliates to create such linkages (Glass and Saggi 1998). Horizontal spillovers however are far less likely owing to the risk of loss of proprietary technology (Javorcik 2004; Kugler 2006; Blalock and Gertler 2008). The empirical studies of inter-industry spillovers of foreign technology on domestic productivity have mixed findings. The stock of foreign technology in India is found to generate positive domestic productivity spillovers in 13 out of 26 manufacturing sectors (Kathuria 2000). Further, analyses of the impact of the 1991 Indian economic reforms on manufacturing find significant increases in productivity in import-competing manufacturing 
sectors (Topalova and Khandelwal 2011) as well as for 'scientific' (i.e., technology-intensive) domestic firms but negative for 'non-scientific' ones (Kathuria 2002). These findings contrast with those of Keller and Yeaple (2009) for the USA, where productivity spillovers from imports are insignificant. One explanation for these differential results is the magnitude of the gap between domestic and foreign technologies, which might be expected to be large for India but small or even negative for many US industries.

The absorptive capacity of host economies to assimilate foreign technology is affected by government policies as well as infrastructure and industry characteristics (Furman et al. 2002). Investment in domestic human capital enhances countries' abilities to adapt new technologies and their innovative capacity (Furman and Hayes 2004). Many industrializing economies are investing heavily in human capital formation, particularly in science and technology, to stimulate domestic R\&D activity and reduce their technology gap through imitation and reverse engineering (Alvarez and Robertson 2004; Almeida and Fernandes 2008). The R\&D embodied in foreign technology has significant indirect spillover effects on domestic innovation (Katrak 1990; Lumenga-Neso et al. 2005; Schiff and Wang 2008), while for Chinese firms, the productivity effects of foreign technology depend, at least partly, upon interaction with in-house R\&D (Hu et al. 2005; Liang and Zhang 2012).

Technology spillovers may also enhance the competitiveness of domestic firms although this depends upon a small technology gap (Cantwell 1989; Kokko 1994), a greater absorptive capacity of labour, competitive intensity (Sjöholm 1999), level of internationalization (Baily et al. 1995; Xu and Sheng 2012) and the rate of adoption by competitors (Evenson and Westphal 1995). Firms that are less trade-oriented however are also shown to have greater scope to benefit from foreign technologies (Blomström and Sjöholm 1999), i.e., to improve their efficiency. A major constraint for domestic firms may be the cost of acquisition along with the negative output effects of any initial learning period, even for standard technologies (Amiti and Khandelwal 2013). It is important to note that competition spillovers may be negative if domestic firms are 'crowded out' by more efficient foreign affiliates, particularly where the market is limited as in small and/or developing countries (see Driffield and Read 2004; Read 2018).

An early study of Egypt finds that the domestic productivity impact of Western capital in the period 1952-1985 was substantially greater than that of Eastern European and domestic capital (Karake 1988). The contribution of total factor productivity to output growth was small relative to that of physical inputs, suggesting that foreign technology had little effect on the productivity of domestic labour. Massoud (2008) analyses the growth effects of FDI in three sectors in Egypt 1974-2007 and finds that these are positive only for manufacturing and then only when interacting with human capital. Hanafy (2015) finds similar results although without positive interaction effects with human capital in manufacturing. Elkomy et al. (2018) find that the FDI in Egypt 1990-2007 has positive growth effects in resource-based sectors but negative ones in services, suggesting possible crowding out of domestic investment and a lack of absorptive capacity.

The current paper empirically examines the effect of foreign technology and foreign innovative capital stock - measured by foreign $\mathrm{R} \& \mathrm{D}$ - on productivity in Egyptian manufacturing with reference to their differential sectoral and internationalization characteristics. By incorporating these variables in a production function, this approach is intended to capture the efficiency effects and indirect knowledge spillovers of foreign technology that are not fully accounted for by physical capital accumulation. In so doing, it addresses three specific research questions. (i) To what extent are foreign technology and its embodied $\mathrm{R} \& \mathrm{D}$ in Egypt associated with positive productivity effects and efficiency spillovers as a 
result of knowledge transfers? (ii) Are more internationally oriented domestic firms better able to transform foreign technological innovations into improved performance? (iii) Do domestic firms in more technology-intensive sectors exhibit positive efficiency spillovers from foreign technology?

\section{Methodology}

This study follows Aslanoglu (2000), Liu et al. (2000) and Driffield and Love (2007) in estimating the following logarithmic regression equation:

$$
\begin{aligned}
\operatorname{lnLP}_{i t}= & \delta_{0}+\delta_{1} \operatorname{lnKL}_{i t}+\delta_{2} \operatorname{lnML}_{i t}+\delta_{3} \ln \mathrm{WL}_{i t}+\delta_{4} \operatorname{lnWCL}_{i t}+\delta_{5} \operatorname{lnFirmsize}_{i t} \\
& +\delta_{6} \ln \text { Foreign } \operatorname{Tech}_{i t}+\mu_{i}+\nu_{t}+\varepsilon_{i t}
\end{aligned}
$$

where LP is labour productivity, i.e., the ratio of gross value added by total labour employed in industry $i$; and Foreign Tech is foreign capital imports per employee, measured as the annual flow of investment in purchases of foreign machinery and equipment per worker. $\delta_{6}$ is the main coefficient of interest since; if Foreign Tech has a positive and significant impact on labour productivity, domestic industries are able to assimilate advanced imported technologies efficiently. ML is total materials per unit of labour; KL is the capital-labour ratio, measured as the share of fixed capital assets to labour; and Firmsize is the average revenue per firm in each industry, reflecting market structure and some market characteristics (Liu et al. 2000; Melitz 2003; Luttmer 2007). Melitz details the theoretical foundation of examining the effects of trade on industrial productivity as well as the linkages between aggregate productivity in each industry and specific industrial factors, including a proxy for firm size measured as revenues (or profits) according to the number of firms in each industry. Large firm size is expected to generate productivity gains owing to lower average costs arising from economies of scale.

The skill-intensity of labour is measured by two proxy variables: wages (WL), calculated as total remuneration per unit of labour, and the white-collar labour ratio (WCL), measured as the ratio of white-collar workers to total employment. The latter includes entrepreneurs, managers, technicians, specialists, administrators and secretaries. These two proxy variables control for an industry's capacity to adopt advanced foreign technologies (Buckley et al. 2002; Sinani and Meyer 2004; Rosell-Martinez and Sanchez-Sellero 2012). White collar labour identifies labour with certain educational levels and technical abilities, while the average wage rate reflects the mean skill level of labour (Globerman 1979; Balasubramanyam et al. 1999). Since all variables are in logs, the coefficient estimates denote elasticities, while $\mu_{i}$ are industry-specific effects, $\nu_{t}$ are time-specific effects and $\varepsilon_{i t}$ is the random error term.

In addition, the model tests for the impact of foreign R\&D stock embodied in imported capital on domestic labour productivity using the following empirical specification:

$$
\begin{aligned}
\operatorname{lnLP} P_{i t}= & \delta_{0}+\delta_{1} \operatorname{lnKL} L_{i t}+\delta_{2} \operatorname{lnML}_{i t}+\delta_{3} \ln \mathrm{WL}_{i t}+\delta_{4} \operatorname{lnWCL}_{i t}+\delta_{5} \operatorname{lnFirmsize}_{i t} \\
& +\delta_{6} \ln \text { Foreign } \mathrm{R} \& \mathrm{D}_{i t}+\mu_{i}+\nu_{t}+\varepsilon_{i t}
\end{aligned}
$$

In Eq. (2), Foreign R\&D replaces Foreign Tech to test for the presence of productivity spillovers of foreign $R \& D$ arising from imports of foreign capital. This captures the indirect productivity spillovers from new foreign machinery and equipment that accrue from the transfer of new technologies, new intermediate products and the expansion of the variety of 
inputs. Although cross-country foreign R\&D spillovers are examined in the literature (e.g., Lichtenberg and de la Potterie 1998; Xu and Wang 1999; Cecchini and Lai-Tong 2008), the productivity effects of Foreign R\&D are examined here at the industry level. In order to do this, the unbiased weighting scheme suggested by Lichtenberg and de la Potterie (1998) is employed which provides a correction to the empirical framework, as proposed by Coe and Helpman (1995). Foreign R\&D in industry $i$ in year $t$ is therefore calculated as

$$
\text { Foreign } \mathrm{R} \& \mathrm{D}_{i t}=\frac{\mathrm{CM}_{i t} S_{i t}^{d}}{Y_{i t}}
$$

where $\mathrm{CM}_{i t}$ refers to total capital imports, $S_{i t}^{d}$ is the total R\&D stock in all OECD countries in industry $i$ in year $t$ and $Y_{i t}$ is the total output of that industry in all OECD countries. ${ }^{1}$ This formula corrects for the bias in the weighting scheme by reflecting both the intensity and the direction of industry flows of $\mathrm{R} \& \mathrm{D}$, hence multiplying foreign technology by the OECD $\mathrm{R} \& \mathrm{D} /$ output ratio in each industry.

Foreign $R \& D$ capital stock is computed from the annual $R \& D$ investment for each industry using the permanent inventory method:

$$
S_{i t}^{d}=\frac{I_{i t}}{1-\left[(1-\lambda) /\left(1+r_{t}\right)\right]}
$$

where $I_{i t}$ is the R\&D investment in industry $i$ in year $t, r_{t}$ is the annual growth rate of annual $\mathrm{R} \& \mathrm{D}$ investment and $\lambda$ is the depreciation rate, which is assumed to be $10 \%$ per year (Cecchini and Lai-Tong 2008). Imports of capital machinery and equipment from OECD countries constituted, on average, 76\% of Egypt's total capital imports from 2000 to 2010 (UNCTAD 2013). This suggests that foreign $R \& D$ stocks embodied in capital imports from the OECD may be an important channel for technology spillovers.

The analysis uses individual 2-digit industrial R\&D and output data for the 25 OECD countries from the OECD's ANBERD and STAN databases (OECD nd a; nd b). The aggregate variable for Foreign $R \& D$ is constructed as outlined above. It would be desirable to have the data for Egyptian capital imports disaggregated by industry and country of origin to reflect the relative weight of foreign innovation by each country of origin but these are not available. Instead, the abovementioned proxy measure is used to represent foreign technological intensity and the scale of international innovation in each industry channelled through capital imports.

The use of panel data enables a comparison of the results, both with and without controlling for unobserved heterogeneity by industry, using industry fixed effects. The reporting of the results proceeds sequentially. First, any fixed effects are excluded; second, they are included to control for average heterogeneity per industry. These effects control for any industry-specific, time-invariant, variation. In order to examine the validity of the fixed effects approach vis-à-vis the random effects model, the Hausman test is employed which, in essence, tests for correlation between the regressors and the fixed effects. Here, the null hypothesis of no correlation is rejected, suggesting that the fixed effects model is the preferred specification. All of the regressions reported below include standard errors clustered by industry; this controls for heteroskedasticity and correlation of the error terms within each industry.

\footnotetext{
${ }^{1}$ i.e., Australia, Austria, Belgium, Canada, Czech Republic, Estonia, Finland, France, Germany, Greece, Hungary, Iceland, Ireland, Italy, Japan, Korea, S., Mexico, Netherlands, Norway, Poland, Portugal, Slovenia, Spain, UK and USA.
} 
There is a potential endogeneity problem in estimating Eqs. (1) and (2). The productivity of labour may depend upon capital imports (Foreign Tech and Foreign R\&D) which, in turn, may also depend upon labour productivity. Likewise, it is often believed to be the case that production inputs (KL and WL) can pose endogeneity problems in an augmented production function, although these may be mitigated by the use of aggregate data. If such problems do exist, then the resulting parameter estimates will be biased. Two-stage least squares (2SLS) instrumental variables are therefore used to test for this simultaneity bias with the results presented in Table 10. Following Wang (2010), a 1-year lag, the square of the 1-year lag and the 2-year lag of the variables of interest are used as instruments. The table shows the $F$ statistics of the excluded instruments in the first stage regressions. This test validates the instruments and shows a high degree of correlation with the instrumented variables. The Sargan test for over-identification does not reject the null hypotheses of no correlation between the instruments and the error term, suggesting that the instruments are valid. A Durbin-WuHausman test is also performed to test for endogeneity. The results show that the null hypotheses that there are no significant differences between the coefficient vectors of the 2SLS and FE procedures cannot be rejected. Therefore, there is no statistical evidence of endogeneity. A generalized methods of moments (GMM) estimation is also conducted to deal with any potential simultaneity between labour productivity and the covariates, as discussed in Section 5 .

\section{Data}

The analysis employs of a panel of 128 four-digit ISIC (International Standard Industrial Classification) industries comprising the whole manufacturing sector in Egypt, 2006 to 2009. The source for the data is Egypt's Annual Census of Industrial Production in Private Establishments issued by the Central Agency for Public Mobilization and Statistics (Government of Egypt, various issues n.d). The census includes data on the number of firms, classification of employment by job, total remuneration and wages, value added, costs of factors of production, domestic and foreign capital formation and fixed assets. On average, around 9500 establishments are covered in each year. As stated earlier, the foreign R\&D measure is obtained from the OECD's ANBERD and STAN databases. The R\&D measure is available for 30 two-digit ISIC industries, and it is assumed that all four-digit industries within each two-digit industry classification have the same level of R\&D. The measure of R\&D intensity is the ratio of $R \& D$ expenditure to total value added per industry in current PPP prices. All nominal values are converted into real terms using the wholesale price index from the World Development Indicators (World Bank 2012) since producer price index data by industry is not available.

In terms of industrial structure, Crude Petroleum and Natural Gas Extraction contributes $84 \%$ of total value added in the manufacturing sector. Pharmaceuticals is the second largest industry in terms of value added, followed by Coke and Refined Petroleum Products, Basic Metals and Non-Metallic Mineral Products. As noted by Page (2012), the absence of manufacturing sector diversification and the lack of industrial sophistication are critical impediments to sustained economic growth in developing countries.

Data for labour productivity $(L P)$, capital intensity $(K L)$, Foreign Tech and value-added share $(V A)$ for the two-digit industry classification based on ISIC Revision 4 are shown in Table 1. It should be noted that the sample includes all industrial activities being undertaken by 
Table 1 Sectoral productivity, capital intensity, foreign technology, value added, trade share, and technological classification

\begin{tabular}{|c|c|c|c|c|c|c|c|}
\hline ISIC & Sector & LP & KL & FT & VA & TS & Tech \\
\hline 06 & Petroleum/natural gas extraction & 58.91 & 12.93 & 25.36 & 84.20 & 0.00 & Med \\
\hline 18 & Printing/media products & 13.84 & 171.63 & 0.05 & 0.22 & 0.22 & Low \\
\hline 19 & Coke/refined petroleum products & 10.34 & 25.81 & 5.72 & 2.74 & 2.32 & Med \\
\hline 23 & Other non-metallic mineral products & 5.59 & 55.35 & 7.09 & 1.58 & 0.23 & Med \\
\hline 11 & Beverages & 3.78 & 33.21 & 16.42 & 0.55 & 0.28 & Low \\
\hline 13 & Textiles & 3.76 & 33.83 & 18.64 & 0.48 & 0.64 & Low \\
\hline 28 & Machinery and equipment nec. & 3.71 & 33.13 & 16.52 & 0.10 & 0.29 & High \\
\hline 20 & Chemical Products & 2.68 & 11.54 & 32.78 & 0.97 & 1.02 & High \\
\hline 33 & Machinery/equipment report & 2.19 & 0.27 & 1.25 & 0.01 & 0.04 & Med \\
\hline 09 & Mining support services & 1.68 & 0.22 & 0.00 & 0.01 & 0.00 & Med \\
\hline 25 & Fabricated metal products & 1.58 & 18.08 & 8.73 & 0.27 & 0.52 & Med \\
\hline 24 & Basic metals & 1.37 & 2.00 & 36.49 & 2.74 & 2.85 & Med \\
\hline 21 & Pharmaceuticals & 1.31 & 1.41 & 16.23 & 2.76 & 0.56 & High \\
\hline 16 & Wood/cork products & 1.10 & 14.74 & 9.35 & 0.03 & 0.46 & Low \\
\hline 17 & Paper products & 1.05 & 6.17 & 40.31 & 0.60 & 1.12 & Low \\
\hline 22 & Rubber/plastic products & 1.02 & 3.36 & 22.10 & 0.48 & 2.03 & Med \\
\hline 10 & Food products & 1.01 & 4.72 & 8.37 & 0.67 & 0.84 & Low \\
\hline 12 & Tobacco products & 0.83 & 0.09 & 18.55 & 0.35 & 2.90 & Low \\
\hline 27 & Electrical equipment & 0.81 & 5.39 & 16.22 & 0.42 & 0.83 & High \\
\hline 36 & Water supply/treatment & 0.75 & 0.05 & 0.00 & 0.00 & 0.01 & Med \\
\hline 26 & Computer/electronic products & 0.70 & 0.64 & 36.54 & 0.11 & 1.30 & High \\
\hline 29 & Motor vehicles & 0.60 & 0.68 & 16.38 & 0.52 & 1.08 & High \\
\hline 32 & Other manufacturing & 0.53 & 1.80 & 12.71 & 0.06 & 0.63 & Med \\
\hline 08 & Other mining/quarrying & 0.51 & 1.00 & 14.46 & 0.05 & 0.20 & Med \\
\hline 30 & Other transport equipment & 0.48 & 1.24 & 29.87 & 0.27 & 0.96 & High \\
\hline 15 & Leather/related products & 0.29 & 0.53 & 17.01 & 0.05 & 0.62 & Low \\
\hline 31 & Furniture & 0.20 & 0.36 & 10.46 & 0.25 & 0.46 & Low \\
\hline 14 & Wearing apparel & 0.16 & 0.21 & 20.83 & 0.99 & 1.02 & Low \\
\hline 01 & Crop/animal production & 0.15 & 2.41 & 3.48 & 0.02 & 0.04 & Low \\
\hline 39 & Remediation activities & 0.08 & 0.07 & 98.50 & 0.00 & 0.26 & Low \\
\hline
\end{tabular}

The reported figures are the mean of the real values of the variables in the four-digit industry from 2006 to 2009. $L P$ is the real value added per unit of labour, and the reported figures are in 100,000LE. KL is the real fixed assets per labour, and the reported values are in 100,000 LE

private entities in the Egyptian economy. The Egyptian annual census of manufacturing also produces data for Mining and Quarrying and Agriculture (i.e., ISIC 06, 08 and 09), including Crop and Animal Production (ISIC 01) and Remediation Activities (ISIC 39) that falls under Water Supply. Crude Petroleum and Natural Gas extraction is the most productive industry, followed by Printing and Media Products, Coke and Refined Petroleum Products and NonMetallic Mineral Products. The most productive industries are therefore extractive industries. The table also shows a positive association between labour productivity and the capital-labour ratio (the correlation is 0.82 ; see also Table 3 ). Those industries with relatively high shares of capital imports however are not necessarily characterized by high capital-labour ratios or high productivity. Remediation Activities, Paper, Computers, Electronic and Optical Products and Basic Metals exhibit the highest Foreign Tech share. Nevertheless, the Crude Petroleum and Natural Gas Extraction, Basic Metals, Chemicals and Paper industries together constitute 67\% of total foreign imported capital in the manufacturing sector. This indicates both the large relative size of the crude petroleum industry and the high capital import shares of the other industries. 
Table 2 Descriptive statistics

\begin{tabular}{lccccc}
\hline Variables & Mean & Median & St. dev & Min. & Max. \\
\hline Labour productivity (LP) & 4.03 & 1.03 & 10.80 & 0.08 & 58.91 \\
Capital-labour ratio (KL) & 14.76 & 2.20 & 32.67 & 0.05 & 171.6 \\
Materials per labour (ML) & 2.44 & 0.70 & 8.50 & 0.00 & 47.19 \\
Wages per labour (WL) & 0.16 & 0.11 & 0.16 & 0.03 & 0.72 \\
White collar ratio (WCL) & 0.29 & 0.26 & 0.12 & 0.12 & 0.65 \\
Firm size (Firmsize) & 1900.5 & 206.9 & 6597.5 & 0.00 & 34,587 \\
Foreign technology (Foreign Tech) & 0.07 & 0.01 & 0.29 & 0.00 & 1.58 \\
Foreign R\&D (Foreign R\&D) & 0.002 & 0.0004 & 0.003 & 0.00 & 0.018 \\
\hline
\end{tabular}

The reported figures are the mean of the real values of the variables in the four-digit industry from 2006 to 2009. White collar ratio is a percentage; firm size is measured in 100,000LE per firm; all other variables are measured in $100,000 \mathrm{LE}$ per labour

The industries in Table 1 are classified into two categories based upon their trade share relative to real value added and technological orientation. Industries are classified as internationally oriented if they have at least a $40 \%$ trade share of value added (the 50th percentile). High-tech industries are those with a relatively high technological endowment, based upon the OECD classification. Medium-tech and high-tech industries are grouped together in line with Carroll et al. (2000), with low-tech industries defined as having a R\&D intensity in production lower than 0.34\% (Hatzichronoglou 1997).

Table 2 presents the descriptive statistics for the variables used in the analysis. In most cases, the mean is much larger than the median, suggesting that the variables are right-skewed; hence estimating the model in natural logs gives better statistical properties. Mining Support Services showed no spending on total materials and zero revenue, since this industry is monopolized by one public firm, whereas the sample data is for private firms. In this industry as well as Water Supply and Treatment, there is no investment in foreign machinery and equipment.

Table 3 reports the correlation coefficients between the variables used in the analysis. The dependent variable, labour productivity, is positively correlated with all of the explanatory variables and is particularly highly correlated with the capital-labour ratio and Foreign Tech. In the report of the regression analysis in the next section, these positive correlations are explored to see whether they hold up in multivariate analysis. Most of the explanatory variables are only weakly correlated with each other, which reduces the likelihood of multicollinearity being a problem for the analysis.

Table 3 Correlation matrix

\begin{tabular}{|c|c|c|c|c|c|c|c|c|}
\hline & $1-$ & $2-$ & $3-$ & 4- & $5-$ & $6-$ & 7- & $8-$ \\
\hline 1-Ln LP & 1.00 & & & & & & & \\
\hline 2-Ln KL & 0.82 & 1.00 & & & & & & \\
\hline 3-Ln ML & 0.16 & 0.04 & 1.00 & & & & & \\
\hline 4.Ln WL & 0.28 & 0.03 & 0.28 & 1.00 & & & & \\
\hline 5-Ln WCL & 0.28 & 0.16 & 0.14 & 0.33 & 1.00 & & & \\
\hline 6-Ln Firmsize & 0.26 & -0.06 & 0.60 & 0.51 & 0.29 & 1.00 & & \\
\hline 7-Ln Foreign Tech & 0.63 & 0.69 & 0.07 & 0.03 & 0.21 & 0.00 & 1.00 & \\
\hline 8-Ln Foreign $\mathrm{R} \& \mathrm{D}$ & 0.35 & 0.28 & 0.05 & 0.21 & 0.14 & 0.18 & 0.62 & 1.00 \\
\hline
\end{tabular}


Table 4 Productivity effects of foreign technology and foreign R\&D in Egypt; all manufacturing sectors, 20062009

\begin{tabular}{lllll}
\hline $\begin{array}{llll}\text { Dep. variable: } \\
\text { Ln } L P\end{array}$ & $(1)$ & $(2)$ & $(3)$ & $(4)$ \\
& OLS & OLS & FE & FE \\
\hline Ln KL & $0.54^{* * *}$ & $0.58^{* * * *}$ & $0.58^{* * *}$ & $0.61^{* * *}$ \\
& $(0.03)$ & $(0.02)$ & $(0.06)$ & $(0.06)$ \\
Ln ML & $-0.10^{*}$ & $-0.09^{*}$ & -0.05 & -0.05 \\
& $(0.06)$ & $(0.06)$ & $(0.08)$ & $(0.08)$ \\
Ln WL & $0.18^{* * *}$ & $0.17^{* * *}$ & $0.15^{* *}$ & $0.15^{*}$ \\
& $(0.06)$ & $(0.06)$ & $(0.08)$ & $(0.08)$ \\
Ln WCL & 0.05 & 0.07 & 0.01 & 0.02 \\
& $(0.10)$ & $(0.10)$ & $(0.12)$ & $(0.12)$ \\
Ln Firmsize & $0.22^{* * *}$ & $0.21^{* * *}$ & $0.16^{*}$ & $0.15^{*}$ \\
& $(0.04)$ & $(0.04)$ & $(0.09)$ & $(0.09)$ \\
Ln Foreign Tech & $0.05^{* *}$ & & 0.03 & \\
& $(0.02)$ & & $(0.02)$ & 0.01 \\
Ln Foreign R\&D & & 0.01 & & $(0.02)$ \\
& & $(0.02)$ & & 0.54 \\
$\mathrm{R}^{2}$ & 0.80 & 0.79 & 0.55 & 0.35 \\
Root mean sq. error & 0.60 & 0.61 & 0.35 & 363 \\
No. of obs. & 363 & 363 & 363 & 119 \\
No. of groups & - & - & 119 & 18.30 \\
$F$-statistic & 147.90 & 140.59 & 19.80 & 0.00 \\
$p$ value & 0.00 & 0.00 & 0.00 & \\
\hline
\end{tabular}

Standard errors clustered by industry in parentheses. ${ }^{*} p<0.10$; $* * p<0.05 ; * * * p<0.01$

\section{Estimation Results}

This section summarizes the estimation results and the principal findings of this study.

\subsection{The Impact of Foreign Technology and R\&D on Productivity}

The estimation results for the various model specifications testing the first research question regarding the impact of foreign technology and embodied R\&D on productivity in Egypt based upon Eqs. 1 and 2 are presented in Table 4. All standard errors reported are clustered by industry. The ordinary least square (OLS) results are shown in Columns (1) and (2), while those in Columns (3) and (4) include industry fixed effects (FE) from the panel analysis.

The results in Column (1) show that Foreign Tech has a positive and significant effect on domestic industrial productivity in Egypt. This implies that foreign technology induces significant indirect productivity gains and efficiency spillovers that exceed the effect on physical capital accumulation. When controlling for industry fixed effects in Column (3) however, Foreign Tech becomes statistically insignificant. This implies that a large part of the positive effects obtained in Column (1) reflects unobserved industry-specific productivity determinants (Lee 1995). The Foreign R\&D stock embodied in foreign technology is statistically insignificant in both OLS and FE estimations, shown in Columns (2) and (4) respectively. This suggests that Egyptian industries generally lack the human capital and in-house $R \& D$ capacity to capture the productivity effects embodied in foreign $R \& D$, echoing the findings of Hanafy (2015). The capital-labour ratio (KL) has a robust significant positive effect on labour productivity across all specifications of the model and has the largest the coefficient estimate. A $1 \%$ increase in the KL ratio results in an average increase in labour productivity of 
approximately $0.6 \%$. Physical capital accumulation is therefore an important contributor to industrial productivity in Egypt, and industries characterized by relatively high productivity are those with the highest capital-labour ratios. This finding is similar to that of Karake (1988) for the period 1952-1985.

The results for the materials-labour ratio ML show a consistently negative coefficient although it is only significant in the specifications without industry fixed effects. In the data employed, materials include energy which varies significantly in importance across industries. For the largest industries in the Egyptian manufacturing sector- oil and gas, chemicals, petroleum products etc.- - energy represents a significant proportion of the value of material inputs. The relationship between energy and labour productivity however is dependent upon a wide spectrum of additional factors and treated somewhat ambiguously in the literature (e.g., Renshaw 1981; Boyd and Pang 2000). The results here provide some support for the view that energy-saving techniques generate enhanced productivity although the disaggregated results indicate that this effect is being driven primarily by the high technology industries.

The average wage bill WL has a positive and significant effect on labour productivity; a 1 $\%$ increase in the average wage bill increases labour productivity by an average of 0.15 to $0.17 \%$. This suggests that more highly skilled labour, reflected in higher wages, is more productive. The ratio of white collar to total employment WCL has a consistently positive but insignificant effect on labour productivity. This finding refutes the general view in the literature, focusing principally on industrialized economies, that higher concentrations of white-collar workers enhance labour productivity. The correlation between WL and WCL (Table 2) is 0.33 such that these two variables are not highly correlated. Significant labour

Table 5 Productivity effects of foreign technology and foreign R\&D for internationally oriented (HI) and high technology (HT) industries in Egypt

\begin{tabular}{|c|c|c|c|c|c|c|c|c|}
\hline $\begin{array}{l}\text { Dep. variable: } \\
\text { Ln } L P\end{array}$ & $\begin{array}{l}(1) \\
\text { OLS } \\
\text { HI }\end{array}$ & $\begin{array}{l}(2) \\
\text { OLS } \\
\text { HI }\end{array}$ & $\begin{array}{l}(3) \\
\text { OLS } \\
\text { HT }\end{array}$ & $\begin{array}{l}(4) \\
\text { OLS } \\
\text { HT }\end{array}$ & $\begin{array}{l}(5) \\
\text { FE } \\
\text { HI }\end{array}$ & $\begin{array}{l}(6) \\
\text { FE } \\
\text { HI }\end{array}$ & $\begin{array}{l}(7) \\
\text { FE } \\
\text { HT }\end{array}$ & $\begin{array}{l}(8) \\
\text { FE } \\
\text { HT }\end{array}$ \\
\hline Ln KL & $\begin{array}{l}0.35 * * * \\
(0.02)\end{array}$ & $\begin{array}{l}0.36^{* * * *} \\
(0.03)\end{array}$ & $\begin{array}{l}0.56 * * * \\
(0.04)\end{array}$ & $\begin{array}{l}0.59 * * * \\
(0.03)\end{array}$ & $\begin{array}{l}0.26^{* * * *} \\
(0.08)\end{array}$ & $\begin{array}{l}0.27 * * * \\
(0.08)\end{array}$ & $\begin{array}{l}0.60 * * * \\
(0.08)\end{array}$ & $\begin{array}{l}0.63 * * * \\
(0.09)\end{array}$ \\
\hline Ln ML & $\begin{array}{l}0.15 * * * \\
(0.04)\end{array}$ & $\begin{array}{l}0.17 * * * \\
(0.04)\end{array}$ & $\begin{array}{l}-0.12 * * \\
(0.06)\end{array}$ & $\begin{array}{l}-0.12^{* * *} \\
(0.06)\end{array}$ & $\begin{array}{l}0.07 \\
(0.17)\end{array}$ & $\begin{array}{l}0.07 \\
(0.17)\end{array}$ & $\begin{array}{l}-0.03 \\
(0.10)\end{array}$ & $\begin{array}{l}-0.02 \\
(0.10)\end{array}$ \\
\hline Ln WL & $\begin{array}{l}0.15^{* * *} \\
(0.07)\end{array}$ & $\begin{array}{l}0.14 * \\
(0.07)\end{array}$ & $\begin{array}{l}0.25 * * * \\
(0.07)\end{array}$ & $\begin{array}{l}0.24 * * * \\
(0.07)\end{array}$ & $\begin{array}{l}0.14^{*} \\
(0.08)\end{array}$ & $\begin{array}{l}0.15^{*} \\
(0.09)\end{array}$ & $\begin{array}{l}0.22 * * * \\
(0.08)\end{array}$ & $\begin{array}{l}0.22 * * * \\
(0.08)\end{array}$ \\
\hline Ln WCL & $\begin{array}{l}0.14 \\
(0.08)\end{array}$ & $\begin{array}{l}0.14 \\
(0.08)\end{array}$ & $\begin{array}{l}0.05 \\
(0.12)\end{array}$ & $\begin{array}{l}0.07 \\
(0.12)\end{array}$ & $\begin{array}{l}0.05 \\
(0.13)\end{array}$ & $\begin{array}{l}0.06 \\
(0.14)\end{array}$ & $\begin{array}{l}0.03 \\
(0.15)\end{array}$ & $\begin{array}{l}0.05 \\
(0.15)\end{array}$ \\
\hline Ln Firmsize & $\begin{array}{l}0.22 * * * \\
(0.03)\end{array}$ & $\begin{array}{l}0.19 * * * \\
(0.03)\end{array}$ & $\begin{array}{l}0.24 * * * \\
(0.04)\end{array}$ & $\begin{array}{l}0.24 * * * \\
(0.05)\end{array}$ & $\begin{array}{l}0.12 \\
(0.12)\end{array}$ & $\begin{array}{l}0.10 \\
(0.12)\end{array}$ & $\begin{array}{l}0.15 \\
(0.11)\end{array}$ & $\begin{array}{l}0.13 \\
(0.11)\end{array}$ \\
\hline Ln Foreign Tech & $\begin{array}{l}0.04 * * \\
(0.02)\end{array}$ & & $\begin{array}{l}0.04 \\
(0.02)\end{array}$ & & $\begin{array}{l}0.05 * * \\
(0.02)\end{array}$ & & $\begin{array}{l}0.05^{* *} * \\
(0.02)\end{array}$ & \\
\hline Ln Foreign R\&D & & $\begin{array}{l}0.03 * * \\
(0.01)\end{array}$ & & $\begin{array}{l}0.01 \\
(0.02)\end{array}$ & & $\begin{array}{l}0.04^{*} \\
(0.02)\end{array}$ & & $\begin{array}{l}0.02 \\
(0.03)\end{array}$ \\
\hline$R^{2}$ & 0.84 & 0.84 & 0.79 & 0.78 & 0.23 & 0.22 & 0.58 & 0.57 \\
\hline Root mean sq. err & 0.39 & 0.39 & 0.63 & 0.63 & 0.28 & 0.28 & 0.37 & 0.37 \\
\hline No. of obs. & 200 & 200 & 230 & 230 & 200 & 200 & 230 & 230 \\
\hline No. of groups & - & - & - & - & 82 & 82 & 77 & 77 \\
\hline$F$-statistic & 174.34 & 171.96 & 79.99 & 79.59 & 4.80 & 4.53 & 14.39 & 12.36 \\
\hline$p$ value & 0.00 & 0.00 & 0.00 & 0.00 & 0.00 & 0.00 & 0.00 & 0.00 \\
\hline
\end{tabular}

Standard errors clustered by industry in parentheses. ${ }^{*} p<0.10 ; * * p<0.05$; *** $p<0.01$ 
productivity gains are also found for larger average firm size (Firmsize), indicating the positive effect of scale economies on firm performance. Controlling for industry fixed effects however reduces the significance of this variable; again suggesting that this result is partly driven by industry-specific characteristics.

\subsection{The Impact on the Productivity of Internationally Oriented and Technology-Intensive Firms}

The estimation results for the analysis of the second research question regarding the impact of foreign technology and R\&D on the productivity of Egyptian firms according to their international and technological orientation are shown in Table 5. Industries are classified as internationally oriented (HI) if their trade share of value added is at least $40 \%$ and as high technology (HT) if their technological intensity accords with the OECD classification.

HI Egyptian industries are found to be more competitive (i.e., more productive) and have a greater capacity to assimilate foreign technologies and the embodied R\&D stock relative to domestic-oriented ones. ML has a positive and significant impact on productivity for the highly internationalized industries and a weaker significant negative impact for the technology-intensive ones. The coefficients of $W L$ generally increase in magnitude, suggesting that higher wages have a greater impact on labour productivity in these industries. The significances of these coefficients for the HT group are consistently very strong but weaker for the HI group relative to those in Table 4. The firm size effects are strongly significant in the OLS estimation but disappear in fixed effects, again suggesting that substantial labour productivity gains for larger firms are driven by industry-specific characteristics.

The results in Columns (1), (2), (5) (6) and (7) of the table reveal evidence of significant productivity spillovers of foreign technology and foreign embodied R\&D, averaging 0.04 to $0.05 \%$. The findings presented in Table 5 therefore provide further support for the view that more internationalized and technology-intensive industries exhibit significantly greater productivity gains and efficiency spillovers from imported technology and foreign R\&D.

\subsection{Productivity Spillovers and TFP Effects on Technology-Intensive Firms}

The results presented in Table 5 also provide support for the third research question regarding whether technology-intensive firms in Egypt in particular possess the capacity to benefit from productivity spillovers from foreign technology. This requires these industries to possess engineers and technologists with the requisite expertise and absorptive capacity to understand, assimilate and utilize the knowledge embodied in imports from industrialized economies (Hatzichronoglou 1997; Boothby et al. 2010). This question highlights the issue of domestic absorptive capacity, which is likely to affect the magnitude and significance of foreign technology spillovers (Liu and Buck 2007; Vogel and Wagner 2010). R\&D embodied in foreign technology however appears not to drive significant productivity gains in the technology-intensive industries, as revealed in Columns (4) and (8) of the table.

The third question is also addressed by estimating the effects of foreign technology and embodied R\&D on total factor productivity (TFP) growth in Egypt to reveal changes in 
Table 6 Effects of foreign technology and foreign R\&D on TFP in Egypt, all manufacturing sectors, 2006-2009

\begin{tabular}{|c|c|c|c|c|}
\hline $\begin{array}{l}\text { Dep. variable: } \\
\text { Ln TFP }\end{array}$ & $\begin{array}{l}(1) \\
\text { OLS-All }\end{array}$ & $\begin{array}{l}(2) \\
\text { OLS-All }\end{array}$ & $\begin{array}{l}(3) \\
\text { FE-All }\end{array}$ & $\begin{array}{l}\text { (4) } \\
\text { FE-All }\end{array}$ \\
\hline Ln WL & $\begin{array}{l}0.10 \text { **** } \\
(0.04)\end{array}$ & $\begin{array}{l}0.10^{* * * *} \\
(0.04)\end{array}$ & $\begin{array}{l}0.13 * * \\
(0.05)\end{array}$ & $\begin{array}{l}0.13 * * \\
(0.05)\end{array}$ \\
\hline Ln WCL & $\begin{array}{l}-0.07 \\
(0.06)\end{array}$ & $\begin{array}{l}-0.05 \\
(0.06)\end{array}$ & $\begin{array}{c}-0.04 \\
(0.08)\end{array}$ & $\begin{array}{l}-0.03 \\
(0.08)\end{array}$ \\
\hline Ln Firmsize & $\begin{array}{l}0.01 \\
(0.01)\end{array}$ & $\begin{array}{l}0.01 \\
(0.01)\end{array}$ & $\begin{array}{l}0.24 * * * \\
(0.03)\end{array}$ & $\begin{array}{l}0.23 * * * \\
(0.04)\end{array}$ \\
\hline Ln Foreign Tech & $\begin{array}{l}0.02 * \\
(0.01)\end{array}$ & & $\begin{array}{l}0.04 * * \\
(0.02)\end{array}$ & \\
\hline Ln Foreign R\&D & & $\begin{array}{l}0.00 \\
(0.01)\end{array}$ & & $\begin{array}{l}0.00 \\
(0.02)\end{array}$ \\
\hline$R^{2}$ & 0.07 & 0.06 & 0.27 & 0.25 \\
\hline Root mean sq. error & 0.34 & 0.34 & 0.27 & 0.27 \\
\hline No. of obs. & 363 & 363 & 363 & 363 \\
\hline No. of groups & - & - & 117 & 117 \\
\hline$F$-statistic & 3.85 & 3.56 & 19.63 & 13.76 \\
\hline$p$ value & 0.00 & 0.01 & 0.00 & 0.00 \\
\hline
\end{tabular}

Standard errors clustered by industry in parentheses. $* p<0.10 ; * * p<0.05 ; * * * p<0.01$

efficiency and technical progress (Nishimizu and Page 1982). The estimation assumes perfect competition in factor markets along with a neo-classical production function (Caselli and Coleman 2006). The production inputs are represented by labour, capital and total materials, with TFP growth measured by the Solow residual (Wang 2010). In the second-stage, the estimated TFP is regressed against the variables of interest; foreign technology, embodied foreign R\&D and the other control variables. The results in Table 6

Table 7 Effects of foreign technology and foreign R\&D for internationally oriented (HI) and high technology (HT) industries on TFP in Egypt

\begin{tabular}{|c|c|c|c|c|c|c|c|c|}
\hline $\begin{array}{l}\text { Dep. variable: } \\
\text { Ln TFP }\end{array}$ & $\begin{array}{l}(1) \\
\text { OLS } \\
\text { HI }\end{array}$ & $\begin{array}{l}(2) \\
\text { OLS } \\
\text { HI }\end{array}$ & $\begin{array}{l}(3) \\
\text { OLS } \\
\text { HT }\end{array}$ & $\begin{array}{l}(4) \\
\text { OLS } \\
\text { HT }\end{array}$ & $\begin{array}{l}(5) \\
\text { FE } \\
\text { HI }\end{array}$ & $\begin{array}{l}(6) \\
\text { FE } \\
\text { HI }\end{array}$ & $\begin{array}{l}(7) \\
\text { FE } \\
\text { HT }\end{array}$ & $\begin{array}{l}(8) \\
\text { FE } \\
\text { HT }\end{array}$ \\
\hline Ln WL & $\begin{array}{l}0.08^{*} \\
(0.04)\end{array}$ & $\begin{array}{l}0.08 * \\
(0.04)\end{array}$ & $\begin{array}{l}0.13 * * * \\
(0.04)\end{array}$ & $\begin{array}{l}0.13 * * * \\
(0.04)\end{array}$ & $\begin{array}{l}0.11 \\
(0.07)\end{array}$ & $\begin{array}{l}0.11 \\
(0.07)\end{array}$ & $\begin{array}{l}0.17 \text { *** } \\
(0.06)\end{array}$ & $\begin{array}{l}0.17 * * * \\
(0.06)\end{array}$ \\
\hline Ln WCL & $\begin{array}{l}0.02 \\
(0.07)\end{array}$ & $\begin{array}{l}0.04 \\
(0.06)\end{array}$ & $\begin{array}{l}-0.11 \\
(0.07)\end{array}$ & $\begin{array}{l}-0.10 \\
(0.07)\end{array}$ & $\begin{array}{l}0.09 \\
(0.10)\end{array}$ & $\begin{array}{l}0.09 \\
(0.10)\end{array}$ & $\begin{array}{l}-0.07 \\
(0.10)\end{array}$ & $\begin{array}{l}-0.05 \\
(0.10)\end{array}$ \\
\hline Ln Firmsize & $\begin{array}{l}0.00 \\
(0.02)\end{array}$ & $\begin{array}{l}0.01 \\
(0.02)\end{array}$ & $\begin{array}{l}0.02 \\
(0.02)\end{array}$ & $\begin{array}{l}0.01 \\
(0.02)\end{array}$ & $\begin{array}{l}0.28 * * * \\
(0.09)\end{array}$ & $\begin{array}{l}0.27 * * * \\
(0.09)\end{array}$ & $\begin{array}{l}0.23 * * * \\
(0.04)\end{array}$ & $\begin{array}{l}0.21 * * * \\
(0.05)\end{array}$ \\
\hline Ln Foreign Tech & $\begin{array}{l}0.01 \\
(0.01)\end{array}$ & & $\begin{array}{l}0.03 * * \\
(0.01)\end{array}$ & & $\begin{array}{l}0.01 \\
(0.02)\end{array}$ & & $\begin{array}{l}0.05 * * \\
(0.03)\end{array}$ & \\
\hline Ln Foreign R\&D & & $\begin{array}{l}-0.01 \\
(0.01)\end{array}$ & & $\begin{array}{l}0.02 \\
(0.01)\end{array}$ & & $\begin{array}{l}0.01 \\
(0.02)\end{array}$ & & $\begin{array}{l}0.02 \\
(0.02)\end{array}$ \\
\hline$R^{2}$ & 0.06 & 0.06 & 0.11 & 0.10 & 0.21 & 0.21 & 0.31 & 0.27 \\
\hline Root mean sq. err & 0.30 & 0.30 & 0.37 & 0.37 & 0.22 & 0.22 & 0.29 & 0.30 \\
\hline No. of obs. & 200 & 200 & 230 & 230 & 200 & 200 & 230 & 230 \\
\hline No. of groups & - & - & - & - & 82 & 82 & 77 & 77 \\
\hline$F$-statistic & 2.22 & 2.24 & 4.57 & 4.47 & 5.46 & 5.54 & 13.71 & 9.20 \\
\hline$p$ value & 0.07 & 0.07 & 0.00 & 0.00 & 0.00 & 0.00 & 0.00 & 0.00 \\
\hline
\end{tabular}

Standard errors clustered by industry in parentheses. ${ }^{*} p<0.10$; ** $p<0.05$; *** $p<0.01$ 
Table 8 GMM estimation of productivity effects of foreign technology \& R\&D on TFP in the Egyptian manufacturing sector

\begin{tabular}{|c|c|c|c|c|c|c|}
\hline $\begin{array}{l}\text { Dep. variable: } \\
\text { Ln } L P\end{array}$ & $\begin{array}{l}\text { (1) } \\
\text { GMM } \\
\text { All }\end{array}$ & $\begin{array}{l}\text { (2) } \\
\text { GMM } \\
\text { All }\end{array}$ & $\begin{array}{l}(3) \\
\text { GMM } \\
\text { HI }\end{array}$ & $\begin{array}{l}\text { (4) } \\
\text { GMM } \\
\text { HI }\end{array}$ & $\begin{array}{l}\text { (5) } \\
\text { GMM } \\
\text { HT }\end{array}$ & $\begin{array}{l}\text { (6) } \\
\text { GMM } \\
\text { HT }\end{array}$ \\
\hline Ln KL & $\begin{array}{l}0.5414 * * * \\
(0.05)\end{array}$ & $\begin{array}{l}0.5980 * * * \\
(0.03)\end{array}$ & $\begin{array}{l}0.3432 * * * \\
(0.04)\end{array}$ & $\begin{array}{l}0.3664 * * * \\
(0.03)\end{array}$ & $\begin{array}{l}0.5267 * * * \\
(0.05)\end{array}$ & $\begin{array}{l}0.5905 * * * \\
(0.04)\end{array}$ \\
\hline Ln ML & $\begin{array}{l}-0.1308^{*} \\
(0.08)\end{array}$ & $\begin{array}{l}-0.1390 * * \\
(0.07)\end{array}$ & $\begin{array}{l}0.1335 * * \\
(2.36)\end{array}$ & $\begin{array}{l}0.1568 * * * \\
(0.06)\end{array}$ & $\begin{array}{l}-0.1293 * \\
(0.07)\end{array}$ & $\begin{array}{l}-0.1251^{*} \\
(0.07)\end{array}$ \\
\hline Ln WL & $\begin{array}{l}0.1388^{*} \\
(0.08)\end{array}$ & $\begin{array}{l}0.1509 * * \\
(0.07)\end{array}$ & $\begin{array}{l}0.0501 \\
(0.37)\end{array}$ & $\begin{array}{l}0.0838 \\
(0.11)\end{array}$ & $\begin{array}{l}0.2376^{* * * *} \\
(0.08)\end{array}$ & $\begin{array}{l}0.2495 \text { *** } \\
(0.06)\end{array}$ \\
\hline Ln WCL & $\begin{array}{l}0.0276 \\
(0.22)\end{array}$ & $\begin{array}{l}0.0660 \\
(0.54)\end{array}$ & $\begin{array}{l}0.1639 \\
(1.10)\end{array}$ & $\begin{array}{l}0.1736 \\
(1.24)\end{array}$ & $\begin{array}{l}-0.0148 \\
(0.14)\end{array}$ & $\begin{array}{l}0.0437 \\
(0.14)\end{array}$ \\
\hline Ln Firmsize & $\begin{array}{l}0.2447 \text { *** } \\
(0.06)\end{array}$ & $\begin{array}{l}0.2419 * * * \\
(0.05)\end{array}$ & $\begin{array}{l}0.2210 * * * \\
(0.06)\end{array}$ & $\begin{array}{l}0.1884 * * \\
(0.05)\end{array}$ & $\begin{array}{l}0.2615^{* * * *} \\
(0.06)\end{array}$ & $\begin{array}{l}0.2380 * * * \\
(0.06)\end{array}$ \\
\hline Ln Foreign Tech & $\begin{array}{l}0.0746^{* * *} \\
(0.04)\end{array}$ & & $\begin{array}{l}0.0718 \\
(0.05)\end{array}$ & & $\begin{array}{l}0.1070 * * * \\
(0.04)\end{array}$ & \\
\hline Ln Foreign R\&D & & $\begin{array}{l}0.0152 \\
(0.03)\end{array}$ & & $\begin{array}{l}0.0296 \\
(0.73)\end{array}$ & & $\begin{array}{l}0.0416 \\
(0.04)\end{array}$ \\
\hline Constant & $\begin{array}{l}-1.2344 * * * \\
(0.40)\end{array}$ & $\begin{array}{l}-1.4403 \\
(0.33)\end{array}$ & $\begin{array}{l}-1.1026 \\
(0.47)\end{array}$ & $\begin{array}{l}-1.0649 \\
(0.37)\end{array}$ & $\begin{array}{l}-0.9844 * * \\
(2.17)\end{array}$ & $\begin{array}{l}-1.0972 * * * \\
(0.42)\end{array}$ \\
\hline No. of obs. & 363 & 363 & 200 & 200 & 230 & 230 \\
\hline No. of groups & 117 & 117 & 82 & 82 & 77 & 77 \\
\hline No. of instrum. & 12 & 12 & 12 & 12 & 12 & 12 \\
\hline Arellano-Bond (1) & 0.003 & 0.007 & 0.015 & 0.018 & 0.013 & 0.033 \\
\hline Arellano-Bond (2) & 0.892 & 0.807 & 0.931 & 0.971 & 0.681 & 1.00 \\
\hline Hansen statistic & 0.294 & 0.509 & 0.015 & 0.040 & 0.785 & 0.727 \\
\hline
\end{tabular}

Standard errors clustered by industry in parentheses. $* p<0.10 ; * * p<0.05 ; * * * p<0.01$

show that foreign technology has positive and significant growth effects on TFP for all manufacturing sectors, in line with Wang. This demonstrates the importance of the diffusion of new technological products and services as a channel for technical progress, so creating a new domestic production frontier driving long run economic growth (Andersson et al. 2016).

The results in Table 7 show that technology-intensive industries in Egypt have experienced significant productivity gains from imports of foreign technology. No significant results however are found for the effect of either foreign technology or embodied R\&D for highly internationalized industries. This implies that the technological change required to drive the industrial frontier outwards may require a certain knowledge threshold that might only be present in technology-intensive industries.

Generalized methods of moments (GMM) is then used to control for potential simultaneity between labour productivity and foreign technology and foreign $R \& D$, following Driffield and Love (2007), and as a robustness check for the results. These results are reported in Table 8. Owing to the short nature of the panel, the depth of the lags is restricted to two periods and a collapsed instrument set is used. The findings in Column (1) reveal positive productivity effects arising from foreign technology of the order of 0.07 percentage points. Those industries with greater relative technological potential however experience larger productivity spillovers from foreign technology of the order of 0.10 percentage points. Caution should be exercised here however owing to the relatively high value of the Hansen statistic (0.681) when GMM estimation is used on the reduced sample 
Table 9 GMM LDV estimation of productivity effects of foreign technology \& R\&D on TFP in the Egyptian manufacturing sector

\begin{tabular}{|c|c|c|c|c|c|c|}
\hline $\begin{array}{l}\text { Dep. variable: } \\
\text { Ln } L P\end{array}$ & $\begin{array}{l}\text { (1) } \\
\text { GMM } \\
\text { All }\end{array}$ & $\begin{array}{l}\text { (2) } \\
\text { GMM } \\
\text { All }\end{array}$ & $\begin{array}{l}\text { (3) } \\
\text { GMM } \\
\text { HI }\end{array}$ & $\begin{array}{l}\text { (4) } \\
\text { GMM } \\
\text { HI }\end{array}$ & $\begin{array}{l}\text { (5) } \\
\text { GMM } \\
\text { HT }\end{array}$ & $\begin{array}{l}\text { (6) } \\
\text { GMM } \\
\text { HT }\end{array}$ \\
\hline $\mathrm{Ln} \mathrm{LP}_{-1}$ & $\begin{array}{l}0.1389 \\
(0.15)\end{array}$ & $\begin{array}{l}0.0899 \\
(0.16)\end{array}$ & $\begin{array}{l}0.4061 * * * \\
(0.15)\end{array}$ & $\begin{array}{l}0.3116^{* * * *} \\
(0.12)\end{array}$ & $\begin{array}{l}0.3018 \\
(0.28)\end{array}$ & $\begin{array}{l}0.0517 \\
(0.23)\end{array}$ \\
\hline Ln KL & $\begin{array}{l}0.4712 * * * \\
(0.10)\end{array}$ & $\begin{array}{l}0.5359 \text { *** } \\
(0.08)\end{array}$ & $\begin{array}{l}0.1537 * * \\
(0.07)\end{array}$ & $\begin{array}{l}0.2288 \text { *** } \\
(0.06)\end{array}$ & $\begin{array}{l}0.3507 * * \\
(0.15)\end{array}$ & $\begin{array}{l}0.5342 \text { *** } \\
(0.13)\end{array}$ \\
\hline Ln ML & $\begin{array}{l}-0.0929 * \\
(0.07)\end{array}$ & $\begin{array}{l}-0.1133 * \\
(0.06)\end{array}$ & $\begin{array}{l}0.1549 * * \\
(0.07)\end{array}$ & $\begin{array}{l}0.1883 \text { *** } \\
(0.06)\end{array}$ & $\begin{array}{l}-0.0464 \\
(0.10)\end{array}$ & $\begin{array}{l}-0.1164 \\
(0.09)\end{array}$ \\
\hline Ln WL & $\begin{array}{l}0.1885 * * \\
(0.10)\end{array}$ & $\begin{array}{l}0.1772 * * \\
(0.09)\end{array}$ & $\begin{array}{l}0.1754 \\
(0.15)\end{array}$ & $\begin{array}{l}0.1949 * \\
(0.12)\end{array}$ & $\begin{array}{l}0.2765^{* *} \\
(0.18)\end{array}$ & $\begin{array}{l}0.2382 * * \\
(0.11)\end{array}$ \\
\hline Ln WCL & $\begin{array}{l}0.0846 \\
(0.56)\end{array}$ & $\begin{array}{l}0.1456 \\
(0.15)\end{array}$ & $\begin{array}{l}-0.0552 \\
(0.19)\end{array}$ & $\begin{array}{l}0.0166 \\
(0.16)\end{array}$ & $\begin{array}{l}-0.0720 \\
(0.20)\end{array}$ & $\begin{array}{l}0.1390 \\
(0.18)\end{array}$ \\
\hline Ln Firmsize & $\begin{array}{l}0.2162 * * * \\
(0.07)\end{array}$ & $\begin{array}{l}0.2324 * * * \\
(0.07)\end{array}$ & $\begin{array}{l}0.0972 \\
(0.07)\end{array}$ & $\begin{array}{l}0.0806 \\
(0.06)\end{array}$ & $\begin{array}{l}0.1912 * \\
(0.11)\end{array}$ & $\begin{array}{l}0.2708 * * * \\
(0.10)\end{array}$ \\
\hline Ln Foreign Tech & $\begin{array}{l}0.0391 \\
(0.04)\end{array}$ & & $\begin{array}{l}0.0917 * * * \\
(0.34)\end{array}$ & & $\begin{array}{l}0.0975^{* *} \\
(0.05)\end{array}$ & \\
\hline Ln Foreign R\&D & & $\begin{array}{l}-0.0034 \\
(0.03)\end{array}$ & & $\begin{array}{l}0.0462 \\
(1.12)\end{array}$ & & $\begin{array}{l}0.0343 \\
(0.04)\end{array}$ \\
\hline Constant & $\begin{array}{l}-0.9630^{*} \\
(0.51)\end{array}$ & $\begin{array}{l}-1.2094 \\
(0.44)\end{array}$ & $\begin{array}{l}-0.1956 \\
(0.55)\end{array}$ & $\begin{array}{l}-0.2674 \\
(0.43)\end{array}$ & $\begin{array}{l}-0.4870 \\
(0.81)\end{array}$ & $\begin{array}{l}-1.1484 * \\
(0.70)\end{array}$ \\
\hline No. of obs. & 262 & 262 & 153 & 153 & 166 & 166 \\
\hline No. of groups & 110 & 110 & 73 & 73 & 70 & 70 \\
\hline No. of instrum. & 12 & 12 & 12 & 12 & 12 & 12 \\
\hline Arellano-Bond (1) & 0.042 & 0.075 & 0.053 & 0.066 & 0.109 & 0.154 \\
\hline Arellano-Bond (2) & $\mathrm{n} / \mathrm{a}$ & $\mathrm{n} / \mathrm{a}$ & $\mathrm{n} / \mathrm{a}$ & $\mathrm{n} / \mathrm{a}$ & $\mathrm{n} / \mathrm{a}$ & $\mathrm{n} / \mathrm{a}$ \\
\hline Hansen statistic & 0.361 & 0.549 & 0.695 & 0.376 & 0.500 & 0.479 \\
\hline
\end{tabular}

Standard errors clustered by industry in parentheses. ${ }^{*} p<0.10 ; * * p<0.05$; *** $p<0.01$

$n / a$ not available

containing only the technology-intensive industries. The results for the highly internationalized industries are not statistically significant, which implies that in this context, trade openness at the industry level is not necessarily associated with a greater capacity to adopt foreign technological progress. Finally, foreign embodied R\&D does not achieve statistical significance in any specification of the model. ${ }^{2}$

The estimation process is completed by the results from a dynamic GMM specification, presented in Table 9. For four of the six models, the coefficient on the lagged dependent variable (LDV) is insignificant. For the internationally oriented industries however, the findings reported in Columns (3) and (4) show that the parameter estimate is significant at the $1 \%$ level, implying a degree of persistence in the productivity series for these industries. Furthermore, foreign technology in (3) is now also significant at the $1 \%$ level. In both empirical specifications for the internationally oriented industries, firm size loses significance when an LDV is included. These results might seem to point to the superiority of a dynamic specification for certain industry types but the value of the Hansen statistic for (3) is almost

\footnotetext{
${ }^{2}$ As the estimation period covers the global financial crisis, the FE models were also re-estimated to include time effects and the GMM model was re-estimated augmented with time dummies. In all cases, these time effects failed to achieve statistical significance and the other parameter estimates were invariant to their inclusion. These results are available upon request in Supplemental Tables.
} 
0.7 , driven by a small number of observations that is exacerbated by the inclusion of the LDV. A rigorous test of the robustness, or otherwise, of the dynamic model therefore requires a larger sample.

\section{Conclusions and Policy Implications}

This paper investigates the domestic productivity and spillover effects of foreign technology and its embodied R\&D on Egyptian industries, 2006 to 2009. In so doing, it also analyses the heterogeneous impacts of technology transfer across sectors, focusing specifically on internationally oriented (HI) and technology-intensive (HT) industries. This facilitates an exploration of differences in the importance and magnitude of productivity spillovers in industries with greater exposure to foreign competition and a higher technological capacity. These industries are anticipated to possess greater absorptive capacity and are therefore expected to generate greater learning and efficiency spillover effects, reflected in higher productivity. As such, this study is the first to analyse the effect of international $R \& D$ stocks at the industrial level by classifying industries according to their degree of both internationalization and technological intensity using the unbiased weighting scheme suggested by Lichtenberg and de la Potterie (1998). The principal findings of this study are as follows.

Foreign technology and embodied R\&D is found to have generally positive and significant effects on domestic productivity in Egyptian manufacturing, suggesting that there are significant efficiency spillovers over and above physical capital accumulation. A large part of these productivity effects however are revealed to be industry-specific when controlling for fixed effects such that Egyptian manufacturing as a whole lacks sufficient absorptive capacity to capture these productivity spillovers. HI and, in particular, HT industries in Egypt are found to have a greater absorptive capacity for foreign technology, with significant productivity spillovers of between 0.4 and $0.5 \%$. The aggregate growth effects of foreign technology on total factor productivity (TFP) for all Egyptian manufacturing sectors are found to be positive and significant, suggesting that the diffusion of foreign technology is contributing to the country's long-run economic growth. The specific TFP effects on HT industries are found to be positive and significant but not for HI ones, suggesting that only the former industries have attained a possible threshold level of knowledge. GMM estimation confirms the OLS and panel data findings, with overall productivity effects of foreign technology of around $0.07 \%$, rising to $0.10 \%$ for HT industries. The insignificant results for $\mathrm{HI}$ industries however suggest that openness to trade has not enhanced their capacity to absorb foreign technological progress.

The findings of this study of Egypt generate several important general policy implications for developing countries regarding the domestic growth effects of foreign technology. A key benefit derived by developing countries from inflows of FDI is that they are able to enhance their domestic technology stock without incurring the high cost of innovation, leading to potential improvements in the productivity of domestic labour. The findings in this paper however highlight the heterogeneous sectoral productivity effects of foreign technology according to industry-specific factors, which include the absorptive capacity of their labour forces and the possible existence of knowledge thresholds. For Egypt, these effects are found here to be greatest for technology-intensive (HT) industries with less significant impacts on highly internationalized (HI) industries. 
Table 10 IV and endogeneity testing: $F$-statistic, Sargan test, and Durbin-Wu-Hausman statistics

\begin{tabular}{|c|c|c|c|c|}
\hline $\begin{array}{l}\text { Dep. variable } L n L P \\
\text { Test }\end{array}$ & Ln Foreign Tech & Ln Foreign $R \& D$ & $\operatorname{Ln} K L$ & Ln $W L$ \\
\hline \multicolumn{5}{|l|}{ First-stage regressions } \\
\hline F statistic for under-identification & 10.40 & 21.13 & 3.61 & 4.48 \\
\hline $\mathrm{F}$ test $p$ value & $(0.00)^{* * *}$ & $(0.00)^{* * *}$ & $(0.03)^{* *}$ & $(0.01)^{* *}$ \\
\hline \multicolumn{5}{|l|}{ Second-stage regressions } \\
\hline Sargan statistic for over-identification & 4.31 & 2.61 & 1.07 & 1.69 \\
\hline Chi square $p$ value & $(0.11)$ & $(0.10)$ & $(0.29$ & $(0.19)$ \\
\hline \multicolumn{5}{|l|}{ Endogeneity test } \\
\hline Durbin-Wu-Hausman test for endogeneity & 12.04 & 12.22 & 2.54 & 5.39 \\
\hline Chi-square $p$ value & $(0.10)$ & $(0.10)$ & $(0.86)$ & $(0.49)$ \\
\hline
\end{tabular}

Standard errors clustered by industry in parentheses. ${ }^{*} p<0.10 ; * * p<0.05$; ***p $p 0.01$

The general consensus among existing empirical studies is that the spillover effects of foreign technology are important because they also enhance the domestic stocks of technology and knowledge (e.g., Madsen 2007; Cassiman and Golovko 2011). The findings here for HI industries in Egypt however suggest that the productivity effects of trade openness may be limited if domestic absorptive capacity is insufficient. Policy-makers should therefore promote the accumulation of local technological competences by prioritising technical assistance and knowledge transfers from foreign firms (Bozeman 2000).

\section{Compliance with Ethical Standards}

Conflict of Interest The authors declare that they have no conflict of interest.

\section{Appendix}

Open Access This article is licensed under a Creative Commons Attribution 4.0 International License, which permits use, sharing, adaptation, distribution and reproduction in any medium or format, as long as you give appropriate credit to the original author(s) and the source, provide a link to the Creative Commons licence, and indicate if changes were made. The images or other third party material in this article are included in the article's Creative Commons licence, unless indicated otherwise in a credit line to the material. If material is not included in the article's Creative Commons licence and your intended use is not permitted by statutory regulation or exceeds the permitted use, you will need to obtain permission directly from the copyright holder. To view a copy of this licence, visit http://creativecommons.org/licenses/by/4.0/.

\section{References}

Ajakaiye O, Page J (2012) Industrialisation and economic transformation in Africa: Introduction and overview. J Afr Econ 21(2):ii3-ii18

Almeida R, Fernandes AM (2008) Openness and technological innovations in developing countries: evidence from firm-level surveys. J Dev Stud 44(5):701-727

Alvarez R, Robertson R (2004) Exposure to foreign markets and plant-level innovation: evidence from Chile and Mexico. J Int Trade Econ Dev 13:57-87 
Amiti M, Khandelwal AK (2013) Import competition and quality upgrading. Rev Econ Stat 95(2):476-490

Andersson U, Dasí Á, Mudambi R, Pedersen T (2016) Technology, innovation and knowledge: the importance of ideas and international connectivity. J World Bus 51(1):153-162

Aslanoglu E (2000) Spillover effects of foreign direct investments on Turkish manufacturing industry. J Int Dev 12(8):1111-1130

Baily MN, Gersbach H, Scherer FM, Lichtenberg FR (1995) Efficiency in manufacturing and the need for global competition. Brookings Papers on Economic Activity: Microeconomics, 307-58

Balasubramanyam VN, Salisu MA, Sapsford DR (1996) Foreign direct investment and growth in EP and IS countries. Econ J 106(434):92-105

Balasubramanyam VN, Salisu MA, Sapsford DR (1999) Foreign direct investment as an engine of growth. J Int Trade Econ Dev 8(1):27-40

Barry F, Bradley J (1997) FDI and trade: the Irish host-country experience. Econ J 107(445):1798-1811

Bas M, Berthou A (2017) Does input-trade liberalization affect firms' foreign technology choice? World Bank Policy Research Working Paper No. 7883, Washington D.C.: The World Bank

Beck T, Levine R, Loayza N (2000) Finance and the sources of growth. J Financ Econ 58(1-2):1072-1085

Bhagwati JN (1978) Anatomy and consequences of exchange control regimes, Vol. 1, Studies in International Economic Relations No. 10. NBER, New York

Blalock G, Gertler P (2008) Welfare gains from foreign direct investment through technology transfer to local suppliers. J Int Econ 74(2):402-421

Blomström M, Sjöholm F (1999) Foreign direct investment, technology transfer and spillovers: does local participation with multinationals matter? Eur Econ Rev 43(4):915-923

Bloom N, Draca M, Van Reenen J (2016) Trade induced technical change? The impact of Chinese imports on innovation, IT and productivity. Rev Econ Stud 83(1):87-117

Boothby D, Dufour A, Tang J (2010) Technology adoption, training and productivity performance. Res Policy 39(5):650-661

Borensztein E, De Gregorio J, Lee J-W (1998) How does foreign investment affect economic growth? J Int Econ 45(2):115-135

Boyd GA, Pang JX (2000) Estimating the linkage between energy efficiency and productivity. Energy Policy 28(5):289-296

Bozeman B (2000) Technology transfer and public policy: a review of research and theory. Res Policy 29(4-5): $627-655$

Brada J, Hoffman D (1985) The productivity differential between Soviet and Western capital and the benefits of technology imports to the Soviet economy. Quarterly Rev Econ Business 25(1):6-18

Buckley P, Clegg J, Wang C (2002) The impact of inward FDI on the performance of Chinese manufacturing firms. J Int Bus Stud 33(4):637-655

Burstein A, Cravino J, Vogel J (2013) Importing skill-biased technology. Am Econ J Macroecon 5(2):32-71

Burstein A, Vogel J (2017) International trade, technology and the skill premium. J Polit Econ 125(5):1356-1412

Cantwell JA (1989) Technological Innovation \& Multinational Corporations. Basil Blackwell, Oxford

Carroll P, Pol E, Robertson PL (2000) Classification of industries by level of technology: an appraisal and some implications. Prometheus: Critic Stud Innov 18(4):417-436

Caselli F (2005) Accounting for cross-country income differences. In: Aghion P, Durlauf SN (eds) Handbook of economic growth, Vol. 1A. Elsevier, Rotterdam, pp 679-741

Caselli F, Coleman J (2006) The world technology frontier. Am Econ Rev 96(3):499-522

Caselli F, Wilson D (2004) Importing technology. J Monet Econ 51(1):1-32

Cassiman B, Golovko E (2011) Innovation and internationalization through exports. J Int Bus Stud 42(1):56-75

Cecchini L, Lai-Tong C (2008) The links between openness and productivity in Mediterranean countries. Appl Econ 40(6):685-697

Chamarbagwala R, Ramaswamy S, Wunnava PV (2000) The role of foreign capital in domestic manufacturing productivity: empirical evidence from Asian economies. Appl Econ 32(4):393-398

Chuang Y, Hsu P (2004) FDI, trade and spillover efficiency: evidence from China's manufacturing sector. Appl Econ 36(10):1103-1115

Coe D, Helpman E (1995) International R\&D spillovers. Eur Econ Rev 39(5):859-887

Coe D, Helpman E, Hoffmaister A (1995) North-south R\&D spillovers. National Bureau of Economic Research. Working Paper no.5048. Washington DC: NBER

de la Potterie B, Lichtenberg F (2001) Does foreign investment transfer technology across borders? Rev Econ Stud 83(3):490-497

De Long B, Summers L (1993) How strongly do developing economies benefit from equipment investment? J Monet Econ 32(3):395-415

de Mello LR (1999) Foreign direct investment-led growth: evidence from time series and panel data. Oxf Econ Pap 51(2):133-151 
Driffield N, Love J (2007) Linking FDI and host economy productivity effects: conceptual and empirical analysis. J Int Bus Stud 38(3):460-473

Driffield N, Read R (2004) Linkages \& Flow-On Impacts of Foreign Investment in Pacific Island Economies, final report. Sydney, FIAS (World Bank)/Pacific Islands Forum

Easterly W, Levine R (2001) Its not factor accumulation: stylized facts and growth models. World Bank Econ Rev 15(2):177-219

Elkomy S, Ingham H, Read R (2018) FDI and growth in Egypt: published as Aggregate and heterogeneous sectoral growth effects of foreign direct investment in Egypt. Rev Dev Econ 24, 2020. https://doi. org/10.1111/rode. 12698

Evenson R, Westphal L (1995) Technological change and technology strategy. In Behrman, J. and Srinivasan, T.N. (Eds.). Handbook of Development Economics, Vol.3, Part A, 2209-99

Findlay R (1978) Relative backwardness, direct foreign investment and the transfer of technology: a simple dynamic model. Q J Econ 92(1):1-16

Furman JL, Hayes R (2004) Catching up or standing still? National innovative productivity among 'follower' countries, 1978-1999. Res Policy 33(9):1329-1354

Furman JL, Porter ME, Stern S (2002) The determinants of national innovative capacity. Res Policy 31(6):899-933

Gerschenkron A (1962) Economic backwardness in historical perspective. Belknap Press, Cambridge

Glass A, Saggi K (1998) International technology transfer and the technology gap. J Dev Econ 55(2):369-398

Globerman S (1979) Foreign direct investment and 'spillover' efficiency benefits in Canadian manufacturing industries. Can J Econ 12(1):42-56

Government of Egypt, various issues. Annual census of industrial production in private establishments (n.d.) Cairo: Central Agency for Public Mobilization \& Statistics

Grossman G, Helpman E (1991) Comparative advantage and long-run growth. Am Econ Rev 80(4):796-815

Halpern L, Koren M, Szeidl A (2006) Imports and productivity. Federal Reserve Bank of New York, New York (mimeo)

Hanafy S (2015) Sectoral FDI and economic growth: evidence from Egyptian governorates. MAGKS joint discussion paper in economics 37-2015, Universität Marburg

Hanushek EA (2013) Economic growth in developing countries: the role of human capital. Econ Educ Rev 37 : 204-212

Hasan R (2002) The impact of imported and domestic technologies on the productivity of firms: panel data evidence from Indian manufacturing firms. J Dev Econ 69(1):23-49

Hatzichronoglou T (1997) Revision of the high-technology sector and product classification. Technology \& Industry Working Papers No.2. Paris: OECD

Hejazi W, Safarian E (1999) Trade, foreign direct investment and R\&D spillovers. J Int Bus Stud 30(3):491-511

Hendricks L (2000) Equipment investment and growth in developing countries. J Dev Econ 61(2):335-364

Hu AGZ, Jefferson GH, Guan X, Qian J (2005) R\&D and technology transfer: firm-level evidence from Chinese industry. Rev Econ Stat 87(4):780-786

Javorcik BS (2004) Does foreign investment increase the productivity of domestic firms? In search of spillovers through backward linkages. Am Econ Rev 94(3):603-627

Karake ZA (1988) Effects of Eastern European and Western technologies on LDCs: a macroeconometric analysis. Appl Econ 20(8):1099-1114

Kathuria V (2000) Productivity spillovers from technology transfers to Indian manufacturing firms. J Int Dev 12(3):343-369

Kathuria V (2002) Liberalisation, FDI and productivity spillovers - an analysis of Indian manufacturing firms. Oxf Econ Pap 54(4):688-718

Katrak H (1990) Imports of technology and the technological effort of Indian enterprises. World Dev 18(3):371-381

Keller W (1998) Are international R\&D spillovers trade-related? Analysing spillovers among randomly matched trade partners. Eur Econ Rev 42(8):1469-1481

Keller W (2000) Do trade patterns and technology flows affect productivity growth? World Bank Econ Rev 14(1):17-47

Keller W (2004) International technology diffusion. J Econ Lit 42(3):752-782

Keller W, Yeaple S (2009) Multinational enterprises, international trade and productivity growth: firm-level evidence from the United States. Rev Econ Stat 91(4):821-831

Khan MS, Reinhart CM (1990) Private investment and economic growth in developing countries. World Dev 18(1):19-27

Kokko A (1994) Technology market characteristics and spillovers. J Dev Econ 43(2):279-293

Koo BH, Perkins DH (eds) (2016) Social capability \& long-term economic growth. Springer, London

Kugler M (2006) Spillovers from foreign direct investment: within or between industries? J Dev Econ 80(2):444 477

Lall S, Pietrobelli C (eds) (2002) Failing to compete: Technology Development \& Technology Systems in Africa. Edward Elgar, Cheltenham

Lall S, Wangwe S (1998) Industrial policy and industrialisation in Sub-Saharan Africa. J Afr Econ 7(1):70-107

Lee J (1995) Capital goods imports and long-run growth. J Dev Econ 48(1):91-110 
Liang H, Zhang Z (2012) The effects of industry characteristics on the sources of technological product and process innovation. J Technol Transfer 37:867-884

Lichtenberg F, de la Potterie B (1998) International R\&D spillovers: a comment. Eur Econ Rev 42(8):1483-1491

Liu X, Buck T (2007) Innovation performance and channels for international technology spillovers: evidence from Chinese high-tech industries. Res Policy 36(3):355-366

Liu X, Siler P, Wang C, Wei Y (2000) Productivity spillovers from foreign direct investment: Evidence from UK industry-level panel data. J Int Bus Stud 31(3):407-425

Lumenga-Neso O, Olarreaga M, Schiff M (2005) On 'indirect' trade-related R\&D spillovers. Eur Econ Rev 49:1785-1798

Luttmer EG (2007) Selection, growth and the size distribution of firms. Q J Econ 122(3):1103-1144

Madsen JB (2007) Technology spillover through trade and TFP convergence: 135 years of evidence for the OECD countries. J Int Econ 72(2):464-480

Malikane C, Chitambara P (2017) Foreign direct investment, productivity and the technology gap in African economies. J African Trade 4:61-74

Massoud N (2008) FDI and growth in emerging markets: does sectoral distribution matter - the case of Egypt. WP-EMG-05-2008, Cass Business School, London

Mazumdar J (2001) Imported machinery and growth in LDCs. J Dev Econ 65(1):209-224

Melitz MJ (2003) The impact of trade on intra-industry reallocations and aggregate industry productivity. Econometrica 71(6):1695-1725

Nishimizu M, Page JM (1982) Total factor productivity growth, technological progress and technical efficiency change: dimensions of productivity change in Yugoslavia, 1965-78. Econ J 92(368):920-936

Nwaogu UG, Ryan MJ (2015) FDI, foreign aid, remittance and economic growth in developing countries. Rev Dev Econ 19(1):100-115

OECD (n.d.-a) ANalytical Business Enterprise Research \& Development (ANBERD) database. OECD, Paris. https://stats.oecd.org/Index.aspx?DataSetCode=ANBERD REV4. Accessed Dec 2018

OECD (n.d.-b) STructural ANalysis (STAN) database. Paris: OECD. http://www.oecd. org/sti/ind/stanstructuralanalysisdatabase.htm. Accessed Dec 2018

Page J (2012) Can Africa industrialise? J Afr Econ 21(2):ii86-ii124

Pavcnik N (2002) Trade liberalization, exit and productivity improvements: evidence from Chilean plants. Rev Econ Stud 69(1):245-276

Read R (2008) Foreign direct investment in small island developing states. J Int Dev 20(5):502-525

Read R (2018) The determinants and growth effects of foreign direct investment in small economies. In: Briguglio L (ed) Handbook of small states. Routledge, London, pp 386-402

Reggiani C, Shevtsova Y (2018) Trade and productivity in a transition economy: the role of industry and export destination. J Ind Compet Trade 18(3):395-428

Renshaw EF (1981) Energy efficiency and the slump in labour productivity in the USA. Energy Econ 3(1):36-42

Rosell-Martinez J, Sanchez-Sellero P (2012) Foreign direct investment and technical progress in Spanish manufacturing. Appl Econ 44(19):2473-2489

Schiff M, Wang Y (2008) North-south and south-south trade-related technology diffusion: how important are they in improving TFP growth? J Dev Stud 44(1):49-59

Sinani E, Meyer K (2004) Spillovers of technology transfer from FDI: the case of Estonia. J Comp Econ 32(3): 445-466

Sjöholm F (1999) Technology gap, competition and spillovers from direct foreign investment: evidence from establishment data. J Dev Stud 36(1):53-73

Temple J, Voth H (1998) Human capital, equipment investment and industrialization. Eur Econ Rev 42(7):13431362

Topalova P, Khandelwal A (2011) Trade liberalization and firm productivity: the case of India. Rev Econ Stat 93(3):995-1009

UNCTAD (2013) Balance of payment statistics: bilateral trade data. UNCTAD, Geneva

UNESCO (2019). uis.unesco.org/apps/visualisations/research-and-development-spending/. Accessed Dec 2018

Vogel A, Wagner J (2010) Higher productivity in importing German manufacturing firms: self-selection, learning from importing or both? Rev World Econ 145(4):641-665

Wang Y (2010) FDI and productivity growth: the role of inter-industry linkages. Can J Econ 43(4):1243-1272

Wang Y, Blomström M (1992) Foreign investment and technology transfer. Eur Econ Rev 36(1):137-155

World Bank (2012) World development indicators (WDI). The World Bank, Washington DC

Xu B, \& Wang J (1999) Capital goods and R\&D spillovers in the OECD. The Canadian Journal of Economics 32(5):1258-1274

$\mathrm{Xu}$ X, Sheng Y (2012) Productivity spillovers from foreign direct investment: firm-level evidence from China. World Dev 40(1):62-74 
Publisher's Note Springer Nature remains neutral with regard to jurisdictional claims in published maps and institutional affiliations.

\section{Affiliations}

\section{Shimaa Elkomy ${ }^{1} \cdot$ Hilary Ingham ${ }^{2} \cdot$ Robert Read $^{3}$}

Shimaa Elkomy

s.elkomy@surrey.ac.uk

Hilary Ingham

h.ingham@lancaster.ac.uk

1 Surrey Business School, University of Surrey, Guildford GU2 7XH, UK

2 Department of Economics, Lancaster University, Lancaster LA1 4YX, UK

3 Lancaster University Management School, Lancaster LA1 4YW, UK 